\title{
Doing Theology in Hungary: Liberation or Adaptation
}

\author{
JOSEPH PUNGUR
}

\section{The Characteristics of Liberation Theology in Eastern Europe}

Eastern European liberation theology (EELT) is a new branch on the young tree of liberation theologies. It is interesting that the existence of EELT was recognised almost simultaneously in at least three separate places. In the late 1980s Professor Jure Kristo launched a research project entitled 'Liberation Theology and the East European Experience';' Professor Miroslav Volf published the paper 'Democracy and the crisis of the socialist project: toward a post-revolutionary theology of liberation'; ${ }^{2}$ and in 1988 I summarised in ten theses the main principles of EELT, to serve as the basis for a research project on the subject, which resulted in an anthology now in the process of publication with contributions from leading theologians in Eastern and Western Europe and experts in the USA and Canada. I identified the main features of EELT as the following:

1 EELT is born out of Christian responsibility, faced on the one hand with the oppression of Eastern European churches and people by communist regimes, and on the other with the power of the Gospel and its message of liberation from all forms of bondage and oppression.

2 EELT seeks the peaceful liberation of the churches and people of Eastern Europe and constructive cooperation among them.

3 EELT rejects Marxism as a tool of analysis and as the key to the solution of Eastern European problems, because Marxism has in fact been the root cause of those very problems. In this respect, EELT is distinct from other types of liberation theology.

4 EELT uses the Gospel of Jesus Christ as its tool of analysis.

5 EELT looks to the Gospel of Jesus Christ for guidance on how the people of God in Eastern Europe are to be led out of the present spiritual, moral and economic crisis.

6 EELT is based on the Holy Scriptures with due regard for their interpretation in the various Christian traditions.

7 EELT seeks to provide an alternative Christian theology to replace the various corrupted theologies of the Eastern European churches.

8 EELT has respect for a common Christian heritage, fosters Christian fraternity and promotes Christian ideals.

9 EELT is ecumenical and invites theologians and lay people of all Christian traditions to join in and contribute to its aims.

10 EELT provides a model for fruitful cooperation among Eastern European churches, nations and countries on the basis of scriptural principles.

Eastern European liberation theology was born out of a sense of Christian 
responsibility, taking seriously the message that the Gospel of Jesus Christ has power to liberate from all bondage and oppression. Jesus Christ's message of liberation has of course never been denied by the church; but the exact meaning of 'liberation' has been variously understood at different times.

First, the liberating message of Jesus was individualised, on the basis of the fact that in the Gospels this message is aimed first of all at the individual person. The call to 'Repent, for the Kingdom of God is at hand' was addressed to the individuals comprising the crowds which followed Jesus. He granted forgiveness of sins to individuals; it was individual persons he healed.

Second, in the early medieval church, the message of liberation was institutionalised, in consequence of St Augustine's insistence that 'extra ecclesiam non est salus'. The church was understood as the visible presence of the messianic Kingdom of God; whoever is inside the church has been saved. The next step was of course to persuade people to join the church for the sake of their salvation.

Third, the message was overphilosophised, chiefly in the Middle Ages and then in Protestant orthodoxy. Theologians, motivated by the need to preserve the precious message of Jesus, tried to force it into a Procrustean bed of dogmas and doctrines and to construct a comprehensive religious philosophy. In doing so, they emphasised the intellectual character of Christianity, and other aspects tended to be forgotten, inter alia that originally it was a simple teaching of the Master which was meant to be lived out in everyday praxis.

Fourth, the message was overspiritualised, mostly by the revivalist movements which have surfaced from time to time in modern Christian history. The liberating message of Christ was narrowed down to refer to the liberation of the soul from the bondage of sin and its consequences.

While remaining fully aware of the fact that Christ's teaching relates to the individual, EELT takes account of its other dimensions too. EELT recognises that the message of Jesus is directed not only to individuals but to the community as well. Jesus regarded individuals as members of the 'Qahal Jahweh' - the elect people of God. As Christ, he came to make a new covenant between God and his people in the shape of the 'Ecclesia'. EELT recognises that the message of Jesus is not just spiritual in character. His messianic work was radically to change the individual members of the community, and they in turn, as reborn individuals, were to change society. This messianic plan was, indeed, realised in the first three centuries of Christian history. Despite severe persecution of the church, it was not the church but the Roman Empire which disappeared. It could not be otherwise: basic change in society can be brought about only by changed individuals. EELT underlines the importance of this aspect of the teaching of Jesus Christ. By means of a faithful teaching and preaching ministry the Eastern European churches basically followed the methodology of Jesus throughout 40 years of persecution. They changed the minds, souls, personalities and principles of individuals, who at a given point in history were then able to come together to change society by revolutionary but still relatively peaceful means. EELT has always avoided the temptation to develop the simple teachings of Jesus into sophisticated systems, doctrines and dogmas; instead it has emphasised the principles of love, freedom and sacrifice, rooted in a deep faith in God.

Like other liberation theologies, then, EELT takes seriously the liberating message of Jesus Christ: 'If the Son . . . shall make you free, ye shall be free indeed' (John 8:36). This liberating work of Jesus relates not only to the soul of man but to his body too, and claims the whole of human existence, including society. There are similarities and differences between EELT and other liberation theologies. Among the numerous 
liberation theologies the South African and the Latin American are the most developed. All liberation theologies share one common goal: liberation. Liberation from apartheid, segregation and exploitation in South Africa; liberation from oppression, exploitation and marginalisation in Latin America; liberation from foreign domination, oppression and exploitation in Eastern Europe. Where they differ is in their methods. Latin American liberation theologies use Marxism to analyse the situation, and countenance Marxist-inspired revolution as one route to a solution. In Eastern Europe, by contrast, Marxism in its Soviet form has been the root of the problem. In the words of the Polish professor Waldemar Chrostowski,

The Communist experiment in Poland lasted 45 years. It was marked by violence, crime and intimidation, it incapacitated society, it led to the emigration of young and creative people, the ruin of economic, social and political life, and terrible devastation in people's minds and hearts. The destruction is severe and extensive. ... Poles resemble a nation afflicted with a very serious epidemic. Though the epidemic is abating, the return to complete health will take a long time. Since mankind has no previous experience how to recover from Soviet communism, the healing of wounds and scars is a completely unique process. ${ }^{3}$

Chrostowski goes on to quote what he takes to be the reaction of 'Marxist faithful and some liberation theologians' to the failure of communism in Eastern Europe.

Communism as an economic and social theory is a splendid doctrine, guaranteeing the prosperity of the people who choose it as a way of life. In Central and Eastern Europe this doctrine failed for a simple reason: people in this part of the world were not mature enough for communism and were unable to cope with it, and as a consequence they twisted the lofty ideas of its founders and theoreticians. The real solution would be to try again, but this time with awareness of the dangers from immature groups in society. ${ }^{4}$

To this kind of comment we can only reply that a costly and extremely painful 45-year experiment with communism failed miserably, and there is not a shred of evidence that it would be successful next time.

The task of EELT was to liberate people suffering under communist oppression and to create a spiritual milieu where freedom, democracy and development could prevail in an environment of mutual cooperation among Eastern European peoples. This means that EELT is a political theology. Of course, theology of any kind by its very nature tends to be political: it is practised in the 'polis', in human society. The heroic resistance of László Töókés to the Ceauşescu dictatorship in Romania was motivated by his theology and faith, and it triggered the chain-reaction of political events which resulted in a political revolution. No one understood better the political character of Christian theology than the communists. This is why they fought against it and against the churches so bitterly and adamantly. Before going on to look at the role of EELT in encompassing the demise of communism, then, let us look in some detail at an alternative theological option which was available under communism: that of adaptation to the requirements of the regime. We will take the case of Hungary.

\section{Theological Adaptation in Hungary}

Theology is the intellectual function of the church. It is intellectual, for God's call reaches the intellectual faculty of man. Doing theology is the task of the church; by it, 
the church newly expresses the message of God in correlation with the ever-changing world. ${ }^{5}$ Theology basically has a twofold task with regard to the world. First, through the preaching and teaching service of the church, theology calls upon the world to be obedient to the claims of God. This is the missionary task of theology. Second, theology defends the church against the penetration of alien philosophies in order to defend the authentic teaching of the church. This is the apologetic task of theology.

Theological adaptation, in the context of this article, means attempts by theologians to adjust theology to the claims of a political philosophy, that is the ideology of a state. The crucial question for any church is whether and to what extent theology can be so adapted. Some churches undertook theological adaptation in Eastern Europe out of theological considerations. In order to remain modern, they thought, the church had to pay a price, which was its adjustment to the claims of the world. Other churches defended themselves from the influence of the world and did not make any adaptation at all, because they wanted to remain free from the influence and claims of the state.

In this section of the article I shall examine the 'theological adaptation' undertaken by the two main Protestant churches in Hungary. Their leading theologians were seriously involved for some four decades in theological adaptation. Their products were the so-called 'Theology of Service' in the Reformed Church and the 'Theology of Diaconia' in the Evangelical-Lutheran Church in Hungary. The two theologies are very similar as far as their theoretical foundations, socio-ethical consequences and 'Sitz im Leben' are concerned.

\section{The Reformed Church}

The beginnings of the Theology of Service go back to the early post-war years, although some of its elements can be found in the wartime theological works of the late Bishop Imre Révész, Bishop Albert Bereczky and Professor János Victor. ${ }^{6}$ The starting point of this theology was a public confession of sin by the church with regard to the lost war. It appeared in a Declaration of the Synod Council on 9 May 1946, and was probably written by Bishop László Ravasz. ${ }^{7}$ In these early post-war years, amidst political turmoil which ended in the communist takeover of 1948, a new theological trend was in the making at the consultations and meetings of the so-called Reformed 'Free Council' in which Bishop Albert Bereczky played a leading role. The results of this series of consultations were adopted by the church as its official position and were spelled out in the Declaration of the Synod of 30 April 1948. The Declaration stated that 'the church offers itself with whole willingness for every service in the new state and social order which can be done in the name of Jesus Christ and with the power of the Holy Spirit'. ${ }^{8}$ This Declaration paved the way for an Agreement between the Reformed Church and the communist state signed on 7 October $1948 .^{9}$

The Declaration had an enormous impact on the theological development of the church over the next four decades. Quite apart from its content, its existence clearly indicates that the church administration had assumed responsibility not only for the government of the new church, but also for spiritual leadership, teaching and the direction of the church's theology. ${ }^{10} \mathrm{~A}$ Reformed church with an allegedly presbyterian structure thus became a centralised autocracy and remained so for four decades.

With the Declaration and the Agreement began the phase of 'orientation' of the church in the new communist society (1948-58). The church found itself impoverished, deprived of its teaching and missionary functions and forced into a "narrow way' which could easily have led to oblivion. Despite this, the church leaders were more 
than ready to collaborate with the communist state in building a socialist society (where no place was envisaged for the church) and in defending peace (that is, helping to secure international conditions for the final victory of communism).

It was during this phase that the theological basis of the Theology of Service was worked out. Bishop Albert Bereczky played the major role here. ${ }^{11} \mathrm{He}$ talked about his vision of the serving church:

I saw the shining vision of the Hungarian Reformed Church renewed in contrition, faith and thanksgiving, whose joyful privilege is to serve, work and build with cheerful heart on Hungarian soil for the spiritual and material welfare of an earthly fatherland. It has no other claim; only one wish and desire, to follow the Lord who came not to be served but to serve and to give his life as a ransom for many. May God bless and create such a church. 12

The concept of 'Service', which became the cornerstone of this theology, was derived from the Gospels of Luke (19:10 and 22:27) and Matthew (20:28). The argument runs as follows. Jesus Christ came to serve. The church's task is to continue Christ's service in the country where the church finds itself - that is, in Hungary. 'Service' can best be rendered by offering help to the state for the realisation of its own objectives, such as the transformation of a bourgeois society into a socialist one and the preservation of 'peace'. Theology of Service thus took the concept of Christ's 'service' out of context and generalised its application.

The immediate practical consequences were that during the early 1950 s the church supported government policies such as collectivisation of agriculture and the rapid industrialisation of the country, uncritically endorsed the growing dictatorial power of the Communist Party and applauded Stalin and his 'best Hungarian disciple', Rákosi. Meanwhile, within the church, dictatorial power was concentrated in the hands of a small group of leaders.

The process of adaptation by the church was abruptly interrupted by the revolution of 1956. Within hours communist power was crumbling throughout the country and with it the collaborating church leadership; but after the restoration of communist power under János Kádár, the church, under a new leadership, resumed thinking and acting in accordance with the principles of Theology of Service. ${ }^{13}$

The decades between 1957 and 1987 saw the full development of Theology of Service. A central document is the Instruction of the Synod of 1967 on the occasion of the 400th anniversary of the Hungarian Reformed Church. This Synod adopted the Theology of Service as the official theology of the church and in the Instruction summarised its basic principles. While the document stated that in the centre of attention of our church stands the cause of service', it stresses that service 'is not only meditation on the vision of the serving church, but rather doing good works in the name of Christ and in fellowship with Christ'. ${ }^{4}$

The theological argument runs as follows. Christ, the Son of God, the revealer of the sovereign Father, is Lord, but according to the divine law of love is also a servant. His lordship is service, to save man from the slavery of sin and death (Mark 10:45, Phil. 2:5ff). In this service Jesus operates through his church, which is the Body of Christ (1 Cor. 12) and the second mode of Christ's existence. Christ's saving work, which is universal, is called by the New Testament the 'ministry of reconciliation' (2 Cor. $5: 18 f f$ ). Its ultimate goal is that humankind should live 'in peace', which reveals the glory of God. ${ }^{15}$ The theological argument is summarised in an exposition of the ethical principle of the great commandment of Love (Matt. 22:37-40): 
The content of love and the forms of action are not determined by the will of the individual but by the need of his fellow man. There are no eternal ethical norms, only an eternal commandment of love. This is not to be exhausted in emotions but in bringing forth the truth of the weak, the humiliated and the exploited. In the past this attitude on the part of the church helped its transition from the Hellenistic world of the Roman Empire to the Europe of new peoples, from the medieval to the modern world, from Europe to other continents; and it also helps the church in its transition from bourgeois-capitalist society to socialist society. ${ }^{16}$

The Theology of Service produced some socio-ethical principles with major and far-reaching consequences. Firstly, on the basis of this theology the church acknowledged the legitimacy of the socialist revolution taking place in the country and insisted that it was not only right but also necessary. Secondly, the church endorsed the socialist-communist social order and acknowledged its ethical superiority over other social systems. The church therefore supported socialist revolutions in developing countries because only these revolutions could solve their accumulated problems. Thirdly, the church supported the nationalisation of industry and the collectivisation of agriculture, arguing theologically that God gave the land and its wealth to the community in the first place. The church offered help in order that the necessary transformation of society should occur with the minimum trauma possible. Fourthly, the church tried to promote among the population a better work ethic, patriotic sentiments and the values of family life. Fifthly, but by no means least importantly, the church rendered full support to the government in its 'peace work'. This was done chiefly within the framework of the Christian Peace Conference and the National Peace Council, and in the ecumenical movement. ${ }^{17}$

Attempts also were made to rethink the whole traditional theology of the church: Christology, pneumatology, sacramentology, ecclesiology and liturgy were all reinterpreted from the point of view of the Theology of Service. ${ }^{18}$

\section{The Lutheran Church}

Similar theological adaptation was going on in the Evangelical-Lutheran church during the same period. The church experienced some indecisive and hesitant years in the late 1940s, but after the trial and imprisonment of Bishop Lajos Ordass, and after the number of dioceses had been reduced from four to two and two new bishops, Lajos Vetö and László Dezséry, had been installed, the church finally began to adapt itself in theology and in practice to the new communist regime. The process was interrupted by the events of 1956, when Bishop Ordass was rehabilitated. He was soon to be dismissed again, however, and under the autocratic leadership of the new Bishop Zoltán Káldy together with Bishop Lajos Vetö, the church resumed its theological and practical adaptation with the help of the Theology of Diaconia introduced by Bishop Káldy. ${ }^{19}$

In his installation sermon in December 1958 Bishop Káldy clarified the question of so-called 'political worship':

The church and within it the members of the congregation have to fight and work for right order in the world ... this is the issue of practising political responsibility before God, which originates from love toward the world. This is essentially a part of 'diaconia worship'... The Hungarian Evangelical Church cannot renounce the political responsibility she owes to 
our people, living in a new world, and to mankind. Yes, with all our means we want to help in all the good things our people plan to do in building socialism. ${ }^{20}$

To support this theological programme Káldy adduced four theological arguments. Firstly: 'We learned well from Luther that when we serve in this world we are not walking in an alien land but in the imperium of God... God could act through political organisations ... [which are] the "Mask of God".' Secondly: 'The New Testament and Reformation theology talk about the Christian man as the citizen of two realms: the Kingdom of God and this world. In both worlds we have to accomplish our responsibility.' Thirdly, 'Lutheran ethics takes no cognisance of the distinction which would draw a line between churchly and worldly works . . both are churchly works.' Fourthly: 'The love that Christian man received from Christ obliges Christian man to assume political responsibility.'21

Although some of the basic characteristics of the Theology of Diaconia were presented as early as 1958, its fuller conceptualisation can be found in a lecture delivered by Bishop Káldy on the occasion of his honoris causa doctorate in 1964. For the first time he spelled out that "the church can achieve its mission in this world only if this is being carried out in the spirit of "diaconia" ... the content of all the activities of the church is "diakonia".,22 The example for the church is Christ the diakonos, the Servant (Phil. 2:7; Matt. 20:28). Christ made his church diakonos; consequently the church of Christ in its very essence is a serving church. The church should never live for itself; it must not care for itself, but for the people of the world. ${ }^{23}$ In 1964 the Synod of the Evangelical Church adopted the Theology of Diaconia as its official theology.

The social ethics of the Theology of Diaconia were worked out by Bishop Gyula Nagy in his book entitled Egyház a mai világban (the Church in Today's World). In this book the Theology of Diaconia arrives at the same socio-ethical principles as those propounded by the Theology of Service of the Reformed Church. ${ }^{24}$

\section{Responses to the New Theologies}

The new theologies of the historical Protestant churches were welcomed by the communist leaders. In them the regime rightly saw an adaptation to the socialistcommunist system, and everything was done to promote the successful dissemination of the new theologies among the churches in Eastern Europe, and also in the West with the help of the Christian Peace Conference and other ecumenical forums such as the World Council of Churches, the Lutheran World Federation, the World Alliance of Reformed Churches and the Conference of European Churches. A degree of cautious approval was voiced by a few western theologians such as Heinz van Kooten and T. V. Manson; even József Poór, the Hungarian Marxist author, wrote a few lines in praise of these theologies. ${ }^{25}$ Some Hungarian theologians went as far as to state their conviction that the new theologies were of historical and epoch-making importance in the history of theology. ${ }^{26}$

Critical voices raised against the new theologians were louder, however. In a letter to Bishop Bereczky the theologian Karl Barth criticised the new theology and warned Bereczky that he was 'on the point of wandering into an ideological Christian wonderland'. ${ }^{27}$ Sharp criticism was heard at ecumenical gatherings abroad. The chief promoters of the new theologies were dubbed the 'red bishops', indicating their close ties with and subservient attitude towards the communist regime. In 1956, when the 
leaders of the churches were temporarily replaced, representative church gatherings condemned the new theologies by two-thirds majorities; but these expressions of no confidence did not deter the leaders from pursuing the same course after the restoration of communist power.

Professor Vilmos Vajta, a well-known Hungarian-born Lutheran theologian living abroad, was among those who were sharply critical of the Theology of Diaconia. ${ }^{28}$ He notes that the concept of the 'Servant Church' was introduced well before the appearance of the Theology of Diaconia at a meeting of the Conference of European Churches held in Nyborg, Denmark. The Theology of Diaconia, Vajta argues, promotes active cooperation and practical participation in the development of socialist society; but the fundamental element in the 'service' of Jesus Christ was that he gave his life as a ransom for many (Mark 10:45); this profound discussion is neglected in the Theology of Diaconia, where the redemptive element has been replaced by exclusively humanitarian themes. What is more, argues Vajta, Diakonos is only one of the messianic titles of Christ: the oldest title of Christ is Kyrios, 'Lord'; and in a socialist context it is not possible for a church to confess the title Kyrios in its original meaning. The concepts of the suffering Lord and of the disciple who suffers with his Lord are also ignored by the Theology of Diaconia. 'Bearing the cross of Christ' is interpreted simply as 'loving and serving one's neighbour'. Those who suffer injustice at the hands of the regime, however, cannot count on the church's assistance. While Theology of Diaconia criticised racism in South Africa and in North America, and the social conditions in Latin America, it kept silent, for example, when Czechoslovakia was invaded by Warsaw Pact armies in 1968. Theology of Diaconia puts emphasis on solidarity with the state, but without offering any criticism of that state. ${ }^{29}$ The theology also lacks any element of critical self-examination..$^{30}$

Criticism of the Theology of Diaconia could be heard within the Evangelical Lutheran Church in Hungary too. Zoltán Dóka, pastor of a church in Hévizgyörk, sent an open letter to the Lutheran World Federation on 10 July 1984, on the eve of its Seventh Assembly held in Budapest. He sharply criticised what he saw as errors in the Theology of Diaconia:

To the question of what the task of the church in the world is, Diakonia Theology gives the following answer: The task of the church is the proclamation of the Gospel, together with the distribution of sacraments, and the practice of diakonia. With regard to the latter, it is specially emphasised that is not enough for diakonia to deal only with individuals, and that it must extend to the burning questions both of one's own society and of the whole of humanity ... diakonia is not merely the fruit of a faith awakened through the gospel, but is also independent from the gospel, ranked equally with the gospel as the peculiar task of the church ... This false theology makes no distinction between the acts of God and the acts of man, but mixes them and makes them appear equal. ${ }^{31}$

He also called this theology and its application 'the socio-ethical manipulation of the gospel'. It was presented by the church leaders to the pastors as an obligatory theology, and Marxist socialism as an obligatory ideology. ${ }^{32}$ Dóka also drew attention to the autocratic behaviour of Bishop Káldy. 'Everyone who resisted his pressure ... exposed himself to existential danger, as Bishop Káldy continually emphasised this in a manner intended to intimidate the pastors. ${ }^{33}$ Dóka's letter exploded like a bombshell at the Assembly and created huge consternation and division.

It is quite appropriate to criticise the Theology of Service along lines similar to those 
followed by Dr Vajta in his criticism of the Theology of Diaconia. The Theology of Service bases itself on Jesus' statement 'I am among you as one who serves' (Luke 22:27), but Christ directed his words to his own disciples and not, for example, to Pontius Pilate: he was not encouraging his disciples to promote the objectives of Rome. The Theology of Service equates socialism with the Kingdom of God and anticipates the arrival of the latter through the realisation of the former. In promoting socialist-communist objectives, however, this theology prepares the way for its own demolition. ${ }^{34}$ The Theology of Service skilfully uses all the paraphernalia of a genuine theology, but it is not an original theology. It consists of elements borrowed from other theological systems. ${ }^{35}$

Both the theologies we are considering can be labelled heretical in that they have fallen into the trap of Gnosticism. This is because the theologians who created them were convinced that they had 'the knowledge' (gnosis) - namely that the socialistcommunist social system is superior to any other system - and elevated this knowledge to the level of infallible truth. This truth is regarded by them as the revelation of God in history and they put it beside the Scriptures. It was on the basis of this human gnosis that they interpreted the message of the Scripture. Both theologies are marked by features of the 'Docetic' heresy as well. The theologians involved accepted a priori a premise which seemed (dokein) good to them, and made it the cornerstone of their theological system. This was that same premise that socialism-communism is intrinsically superior to any other social system. Events have proved them wrong.

\section{Crumbling of the New Theologies}

In the late 1980s criticism of the Theology of Service and the Theology of Diaconia began to mount steadily within the Protestant churches in Hungary. The main representatives of those theologies began leaving the scene one by one. ${ }^{36} \mathrm{~A}$ new theological fermentation began to characterise church life. In the words of a young Reformed theologian:

The Reformed Church ceased to be an 'opposition' church in the atheist state; it became a church directed by the state and the party with the help of very subservient leaders endorsed by the state-party. The politicising of the church leaders was 'demagogy' and it offered support to the slow withering away of the church according to the theory of 'dying out' adopted and pursued by the state.... In the last decades the Reformed Church was forced to live in a spiritual ghetto, stripped of its centuries-old activities, waiting for slow decay and then dying out according to Marxist theory.... In the last decades theologians made many references to Calvin but they carefully avoided his doctrine of resistance. According to this doctrine, society and even the church have the legitimate right to revolt against a lawless and despotic power. We can understand why this doctrine was not aired in the decades of Stalinism and post-Stalinism, when the leadership of the Reformed Church not only rendered service to the oppressive atheist power but even built up a false ideology, a pseudo-theology - that is a state theology - in the form of the 'Theology of the Narrow Way' or 'Theology of Service'. Instead of promoting witness, this theology promoted guilt feelings, a pseudo-pietist attitude and a fatalist passivity. ${ }^{37}$

Criticism was also growing in the Lutheran Church. On the occasion of the 
dissolution of the State Office for Church Affairs on 15 June 1989 a Lutheran minister commented as follows:

Society is wondering why the hierarchy had not demanded that the State Office for Church Affairs be disbanded.... At this point it becomes obvious that the hierarchy is altogether the creature of that Office. The dismantling of the Office represents an earthquake for the hierarchy.... There have been questions on which the bishops, senior ministers and socalled 'moles' have maintained a discreet silence. For example, they kept silent on the state appointments of 'reliable' persons to leading positions. They kept silent about the advantageous situations and about the rewards they got in the form of prestigious positions or medals and so on, for their 'good services'. They especially kept silent about what the 'good services' covered. It is a fact that these leaders cannot be expected to withstand even the crudest demands of the state; they even overachieved the 'norms' according to their individual ambitions and temperaments. Once in a while they pretended to be naive - which is laughable. They made people near to them believe that they were elected by the church, that they were, indeed, living and dying for the church and that without them Christ's church could not even exist. ... Behind their secret and despotic actions could be felt the power of an almighty state ... there is a shared responsibility... This practice was necessary for the construction of the 'Theology of Obedience' which during the long decades permeated so deeply the soul of the clergy and the believers that they now cannot even imagine life in any other way. In these circumstances even the most humble criticism brought about the accusation of heresy. The hierarchy then took care of the persecution of the heretics. ${ }^{38}$

Amidst mounting criticism of church leaders and theologians, there was a growing demand that those responsible should confess publicly the errors they had committed in devising and promulgating the Theology of Service and the Theology of Diaconia. The leaders were, however, reluctant to do so other than in very general terms - as, for example, in a Communiqué of the Christian Peace Conference, whose president was the Reformed Bishop Károly Tóth:

Now it becomes clear that the hopes for a new social order have not come true ... therefore ... the Christian Peace Conference underlines that the commandment of Christian witnessing for peace... will be not tied to the socialist social order.... It is true that in the difficult years of the Cold War and in a climate of strong ideological pressure [the CPC] compromised and committed faults, and in certain cases yielded to pressure; for this we have to confess our sins and in the spirit of the new times we have to change our working methods as well as our terminology. For this purpose the movement has set up a committee. Its task will be to submit the movement's past to critical examination. ${ }^{39}$

To this vaguely worded call for confession of sins by the Christian Peace Conference, a Reformed minister responded as follows:

They have to confess their sin because of the changed circumstances. This means that if the circumstances had not changed there would have been no need for confession. This proves that it is circumstances that determine the attitude of the Christian Peace Conference.... Its consciousness of $\sin$ is 


\begin{abstract}
being determined by its existence. ... Not its mission but its situation is the determining factor. This is the reason why they summarise the cause of confession in such a concise way: 'in certain cases it yielded to pressure'. What pressure? What are the cases? No matter - all we have to do is to change our working methods. The confession brings about some methodological changes in the CPC. But it also reveals that this is a political organisation, and that its Christianity is only superficial, and not its essence: its consciousness is determined by its existence. This is quite natural in the realm of politics. But it is not so in the realm of the Bible. Following Jesus Christ means that consciousness determines existence. The fact that people never trusted the CPC has to be taken seriously ... for they were always aware that the CPC is an instrument of politics. It is certain that nobody will ever trust it. ... Is it not time to draw the consequences? There are enough world organisations which are trusted. What is the reason for resuscitating an organisation which was never trusted and which is not living in accordance with its consciousness of Christ? ${ }^{40}$
\end{abstract}

The churches thus set out on the path of renewal. The process has been facilitated by the return to the churches of their educational establishments. The Lutheran Church opened its own high school at Budapest-Fasor in September 1989. The Reformed Church received back the historical Colleges of Sárospatak and Pápa, and the Baár-Madas school in Budapest. Teaching began in September 1990. New church organisations have also come into existence: the Association of Hungarian Reformed Ministers, the Reformed Church Renewal Movement, the Reformed Youth Alliance and many others. The publishing activity of the churches has also expanded, and many new periodicals are appearing.

Renewal also means theological renewal. Church leaders and some of the theologians of the old guard, former proponents of the Theology of Service, were soon putting forward the concepts of 'Theology of Peace' and 'Theology of National Consensus' ${ }^{41}$ The radicals, meanwhile, were calling for a new Bible-based theology and a renewal of the huge number of nominal church members through extensive evangelism. Billy Graham led a successful crusade in Budapest in July 1989. The radicals in both churches were demanding the renewal of their churches in capite et in membris. This would inevitably mean the dismissal of those church leaders who had been responsible for the theologies of Service and Diaconia. In the Reformed Church, Bishop Elemér Kocsis was the only bishop to retain his position. Although he had been one of the key exponents of the Theology of Service, he recanted in these terms: 'Our theological ideal is the biblical, confessional, classic Reformed theology, in its modern Barthian reinterpretation. The so-called theology of the "Serving Church" was employed mainly in dialogues with the Marxists.... Since that reason is over, this theology has no role or function any more. 42

\title{
Evaluation of the Theologies of Service and Diaconia
}

A case could be made to show that the original exponents of the Theology of Service and the Theology of Diaconia intended to achieve an honest bargain with the communist masters of their country. The 1948 Agreements between the state and the churches embodied the readiness of church leaders to cooperate in building the new, just and democratic society which to many people still seemed achievable. Before long, however, church leaders began to fear that the new regime, consolidated in the latter 
part of 1948, intended the drastic and ruthless elimination of the church; and the need to avoid offending the authorities became paramount, in order to avoid the slightest reason for open persecution. For many years, moreover, the dream lingered that the Allied powers would prevent the sovietisation of Eastern Europe, including Hungary, and that a war between the western democracies and the Soviet Union was inevitable. The Theology of Service was probably fashioned to serve the survival of the church for a short period.

After the crushing of the 1956 revolution the second generation of defenders of the theologies of Service and Diaconia were probably motivated by a realistic appreciation of the fact that the western democracies were not going to intervene in support of antisoviet insurrections in Eastern Europe, and by the new beginning promised by the Kádár regime: true socialism with a secure place for the church in it. Since a communist future for Hungary was unavoidable, the new leaders of the Protestant churches decided to adapt theologically to the new political reality. Voluntary cooperation on the part of the churches forced Marxist ideologists to rethink and modify their attitude to religion.

Whatever the motives of the church leaders, however, the Theologies of Service and Diaconia were in fact excellent instruments of bondage voluntarily applied by those leaders to their very own churches. In the eyes of the majority of the faithful - both clergy and laity - these theologies were simply a sophisticated means of oppressing freedom, life and service within the churches.

\section{The Praxis of the Captive Church}

Having looked at the theological option of adaptation, let us turn once again to the alternative, which consists in a practical programme of liberation by ordinary believers - clergy and laity - in Eastern Europe. The role of the churches in the recent events in Eastern Europe cannot be properly understood unless one realises that these churches actually executed the praxis of a liberation theology. Developments in these churches constitute a unique case in modern church history. This was a theological movement which was born out of practice and not out of systematic, theological principles: the latter could not in fact come into existence because of the oppressive nature of the communist system. In retrospect, however, it is clear that the involvement of the churches in the changes confirms the latent presence of a liberation theology. During 45 years of oppression, abuse and humiliation - constituting the most severe, sophisticated and systematic persecution since that of the Roman Empire in the first three centuries - the Eastern European churches basically remained faithful to their vocation. They provided - more or less decisively - the spiritual leadership their people needed so badly, kept the flame of liberty and national independence and selfdetermination alive, and provided moral support to their nations in their struggle for freedom. They preserved the rich heritage of the past, and thereby helped to maintain national identity. They were the bridge between the past and the future for these Eastern European nations. A rare moment had arrived for the churches as communism collapsed: they provided not only spiritual but also political leadership.

\section{The Present and Future Tasks of EELT}

With the liberation of the Eastern European states from communism the task of EELT is far from completed. Communism has left devastation and chaos in every realm of life: in the economy, in culture and in society as a whole. In the new situation the task 
of EELT is to guide the churches of Eastern Europe in the construction of truly democratic, just and progressive societies - in the spirit of the Gospel.

The primary task of the churches is the rechristianisation of the post-communist societies of Eastern Europe. In undertaking this task, the churches must be aware that liberals, humanists or radicals would not agree that it is essential. The spiritual devastation of the people of Eastern Europe is so profound, however, that only radical rechristianisation is likely to be able to rescue them from radical cynicism and nihilism. At the same time, the churches need to issue clear warnings about the temptations and dangers of western consumerism.

A related task for the churches is to point out the potential danger inherent in political ideologies, that is, political philosophies based on abstract principles and ideas. Many of the calamities which have befallen Europe in the twentieth century have been the direct consequences of attempts to put such ideologies into practice. EELT has to stress that from now on only those political principles are acceptable which can be measured on the scale of love, since man was created from the love of God and for the love of God and his fellow-men. EELT has nothing to do with abstract philosophical theories: or political ideologies: it follows the example of Jesus Christ the Son of God, who demonstrated in his life and his redemptory death on the cross what practical love really means. He is the ultimate revelation of God and the best example to follow.

EELT is working for a renewed ecumenism among the churches. The churches have traditionally been associated with nationalistic aspirations which have contributed to permanent tensions in the region. Communism did not solve problems relating to nationalism: it merely kept them in suspended animation. Since the collapse of the communist systems, aggressive nationalism has surfaced once again. The role of the churches must be to help the development of a healthy defensive nationalism wherever the human rights of ethnic minorities are in danger. This kind of protective work by the churches was essential during the decades of communist oppression to preserve people's national identity, and it remains so. But the churches must not allow themselves to be used in the cause of aggressive nationalism. Instead, they must make themselves available as bridges between different peoples and nations. This task of the churches arises naturally from the pontifical (priestly) character of their service.

The churches must realise that Eastern European history has now arrived at an important crossroads. The shaping of the twenty-first century has already begun and the churches share responsibility for this process. Historically a three-stage process can be discerned in the political shaping of Eastern Europe. The Holy Roman Empire which emerged from the ruins of the collapsed Western Roman Empire - was the first system, and reached its apogee under the rule of Charlemagne in the ninth century. $\mathrm{He}$ divided his vast Empire among his three sons and the era of European nation-states began. This phase eventually gave way in turn to the era of the imperial states stronger states, such as Sweden, Lithuania, Russia, France, the Austro-Hungarian Empire, Nazi Germany and the Soviet Union, which extended their dominance over the nation-states.

None of these phases has provided permanent stability for the peoples of Eastern Europe. In recent years, however, a new model has emerged, which may offer a longlasting solution, namely the idea of a United Europe, which has its origin in the Western European concept of a Common Market and in some respects resembles the ancient Holy Roman Empire. The churches certainly have an important role to play in making the European Home a real home which will be able to include the peoples of Eastern Europe, and what is essential here is a truly ecumenical spirit. The churches 
must be willing and ready to accommodate each other as brothers and sisters. Proselytism must give way to mutual support for the benefit of all peoples and for the furtherance of the Kingdom of God.

\section{Notes and References}

1 Jure Kristo SJ is professor of theology in Chicago. When I corresponded with him in early 1989 on the issue of EELT he agreed that 'the idea is so appealing that I have been planning to write a book on the subject'. I have subsequently seen his proposal for a project entitled 'Liberation theology and the East European experience'.

2 Miroslav Volf's study was published in Occasional Papers on Religion in Eastern Europe (OPREE), vol. 10, no. 6, November 1990 . Volf is professor of systematic theology at the Evangelical School, Osijek, Croatia.

3 Waldemar Chrostowski, 'Poland: pluralism after the experience of the desert. A Roman Catholic perspective', OPREE, vol. 11, no. 5, October 1991, pp. 18-24. Chrostowski is a professor at the Academy of Catholic Theology in Warsaw.

4 ibid., p. 3.

5 Joseph Pungur, Theology Interpreted (University Press of America, Lanham, 1987), vol. 1, pp. 5-6.

6 Joseph Pungur, 'Protestantism in Hungary: the communist era', in Sabrina Ramet (ed.), Protestantism and Politics in Eastern Europe and Russia: the Communist and PostCommunist Eras (Duke University Press, Durham and London, 1992), pp. 107-56).

7 'Our light was not shining', translation of an article in Reformátusok lapja, 11 February 1990 , p. 5.

8 Imre Jánossy, 'Theological studies', in Studia et Acta Ecclesiastica, vol. V, Tanulmányok a Magyarországi Református Egyház történetéböl (Budapest, 1983), p. 379, translated by J. Pungur.

9 Pungur, 'Protestantism in Hungary', pp. 118-19.

${ }^{10}$ Elemér Kocsis, 'Theological thinking in our church', in Studia et Acta Ecclesiastica, vol. V, p. 563.

11 Besides Bishops Albert Bereczky and János Péter a number of theological professors contributed to the formulation of the Theology of Service, including Janos Victor, L. M. Pákozdy, Elemér Kocsis, Imre Jánossy, L. A. Szabó and Zsigmond Varga.

12 Albert Bereczky, Ajtónyitás (Budapest, 1951), p. 19.

13 Protestant leaders who emerged after 1956 were Bishop Tibor Bartha (Reformed Church), Bishop Zoltán Káldy (Lutheran Church) and Sándor Palotay (Council of Free Churches).

14 Kocsis, op. cit., p. 572.

is ibid., p. 576.

16 ibid., p. 577.

17 ibid., pp. 580-4.

18 In the 1970s and early 1980s a number of theological books expounded the Theology of Service. These included: Tibor Bartha, Ige, Egyház, Nép, 2 vols (Budapest, 1972); Károly Tóth, Örömhir, Békeüzenet (Budapest, 1981); Tóth, Gyökerek és Távlatok (Budapest, 1975); Elemèr Kocsis, Keresztyén etika, 2 vols (Debrecen, 1974, 1979); Kocsis, Dogmatika (Debrecen, 1976).

19 Joseph Pungur, 'Protestantism in Hungary', provides a detailed study of the history of the Evangelical Church in the post-war decades and of the main tenets of the Theology of Diaconia and the Theology of Service.

20 József Poór, A Protestáns theológia Magyarországon 1945-1985 (Kossuth, Budapest, 1986), p. 119.

${ }_{21}$ ibid, pp. 119-20.

22 ibid., p. 122. 
${ }^{24}$ Gyula Nagy, Egyház a mai világban (Budapest, 1967). It is also available in a German translation, Kirche in der heutigen Welt (Budapest, 1967). Other Lutheran theologians involved in working out the Theology of Diaconia were Bishop Lajos Vetö and Professors Miklós Pálfy, Gyula Groó and Károly Pröhle.

25 Poór, op. cit., p. 156.

${ }^{26}$ Kocsis, op. cit., pp. 592-3.

27 Trevor Beeson, Discretion and Valour (Fontana, London, 1974), p. 244.

28 Vilmos Vajta, Die Diakonische Theologie im Gesellschaftsystem Ungarns (Otto Lembeck Verlag, Frankfurt am Main, 1987); Vajta, 'Debatable "Theology of Diaconia"', OPREE, vol. IV, no. 1, 1984, pp. 45ff. See also: 'The Hungarian Lutheran Church and the "Theology of Diaconia"”, Religion in Communist Lands (RCL), vol. 12, no. 2, 1984, pp. 130-48, comprising articles by Vajta and Robert Patkai; John V. Eibner, 'Zoltán Káldy: a new way for the church in socialism?', $R C L$, vol. 13, no. 1, 1985, pp. 33-47.

29 Vajta, 'Debatable "Theology of Diaconia"', pp. $45 \mathrm{ff}$.

30 Vajta, Die Diakonische Theologie ..., pp. $72 \mathrm{ff}$.

31 'Hungarian Lutheran controversy', $R C L$, vol. 13, no. 1, 1985, pp. $98 \mathrm{ff}$.

32 ibid., p. 101.

33 Joseph Pungur, 'Relationship between the Hungarian state and the Hungarian Reformed Church', OPREE, vol. IV, no. 1, 1986, p. 11.

34 ibid.

35 Pungur, 'Protestantism in Hungary', p. 134.

36 Bishop Zoltán Káldy died in 1987, Bishop Tibor Bartha resigned in 1986, and Bishop Gyula Nagy's resignation took effect in 1990.

37 György Pápai Szabó, 'Apolitikus egyház, avagy egyházi struccpolitika', Reformátusok lapja, 21 January 1990, p. 7.

38 Pál Rédey, 'Búcsúzik a Hivatal?', Magyar nemzet, 5 October 1989.

39 'A Keresztyén Békekonferencia nyilatkozata', Reformátusok lapja, 27 January 1990, p. 4.

40 Olivér Czövek, 'A Keresztyén Békekonferencia és a bünbánat', Reformátusok lapja, 28 January 1990 , p. 7.

41 Bill McSween, 'Peace theology in Budapest', $O P R E E$, vol. VIII, no. 3, pp. $1 \mathrm{ff}$.

42 Presbyterian Record (magazine of the Presbyterian Church in Canada), June 1991, p. 45 (quotation from the Hungarian church press). 